\title{
Challenging Misogyny on and off the Pitch: Analysis of Selected Sports Movies
}

\section{Parvathy B. ${ }^{1}$}

\author{
${ }^{1}$ M.A. Student, Institute of English, Thiruvananthapuram, India
}

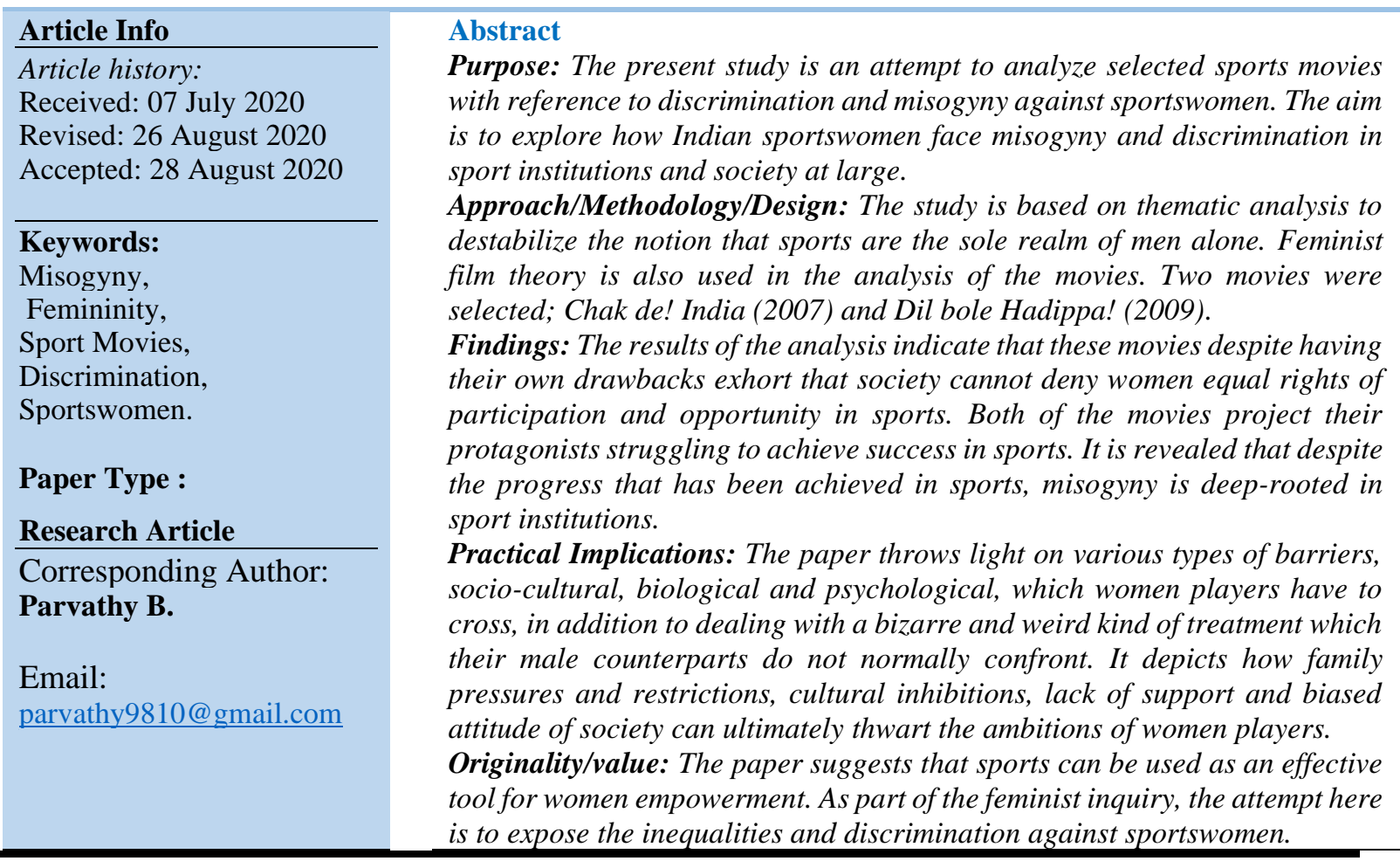

\section{Introduction}

Sports have been recognized as a masculine sphere since ages. This idea persists among the spectators, in spite of the space women have carved out for themselves. Women are still faced with gender equity issues in sports governance, athletic media representation, and perception in sports. The supposition is still that men are the stars and girls are the cheerleaders. When women challenge this as athletes, coaches or commentators, they are often met with complete bitterness. Hence, misogyny is an attitude that has been prevalent in sports since ages. From the time when the first Olympic Games, was held, participation in most sport events was restricted to men alone. Further, married women were even not allowed to watch the events. Sexism has sustained even in the later periods as well, though with relaxations. Even in the modern Olympic games of 1896, women were not allowed to participate. The founder of Modern Olympics Pierre de Coubertin was against the participation of women in the Olympic Games. 
Sports are often viewed as femininity's contrastive factor. Most of the sports events not only differentiate between men and women but also manifest that males are physically superior to women. Media gives men a platform to garner more followers making fewer people want to watch the female athletes play because it seems less desirable or entertaining. While there has been immense progress in the arena of sports, misogyny in sports still persists. Even today women in sports are not portrayed in the same light as their male counterparts.

Although women are equal to men under the law, they are not seen as equals to men in the field of sports (Hanson, 2012). Women can excel men in different events, but the way they are portrayed in the athletic world does not match their actual abilities. It has been 30 years since Title IX legislation granted women equal playing time, but the patriarchal world of journalism still privileges male sports. Coverage of women's sports, for instance, lags far behind men's and mainly the focus is on the female athletes' femininity and sexuality rather than their achievements on the field. Male athletes are framed in accordance with the so called heroic masculine ideals like courage, strength, and endurance. 'Male' is often considered as the synonym of strength in our patriarchal society.

Although various transformations have occurred in the world of sports regarding the ways in which women are represented, objectification of women still prevails. The different discourses and ideologies present in the arena of sports continue to emphasize or normalize the objectification and degrading of women. Misogyny can range from preventing women's involvement in sport events to reinforcing the status of men by comparing it to that of a woman. More importantly, there is an apparent lack of women in leadership positions in sport due to the fact that sport is a gendered institution and that all processes operate within a hegemonic masculine norm (Burton, 2015). Misogyny in sports also includes unfair wages or limited media coverage of women sport events. The values conventionally associated with most sports are identical to that of "manliness". Competitiveness, strength and aggressiveness are values which are not only central to sports but are also qualities strongly related to present-day notions of manliness.

Sports exemplify the ways in which bodies are gendered by collective practices and how the female body is constructed to be inferior in a social context. A woman's body is not portrayed as a strong, muscular machine capable of unusual physical feats like a man's body is, but instead it is looked upon as an object gratifying to the eye when it is exposed outside the realm of sports (Hanson, 2012). Men often look upon a woman as a caretaker, a keeper of the household, a wife, mother, and most often as a tool to satisfy his carnal desires. Such an image arises from television and media-generated stereotypes that portray women cleaning, cooking, and taking care of the household, essentially making life easier for their men and families. Women are always portrayed as an aid to man in fulfilling his needs. Also in visual media, female bodies are exploited through semi-nude photo shoots. Most of the advertisements would feature a woman partially dressed. 
Menstruation and reproduction often acted as a threat before women in the career of a sports woman. Many believed that the participation in sports would make women appear masculine. With the passage of time different organizations have emerged with several approaches to increase the participation rates of women in sports. The concept of masculinity allows men to take for granted that they have the right to express their anger on the bodies of women and to marginalize them. Disrespectful and derogatory language used in sports widens the gender gap. Male coaches often address the male athletes as females whenever they wanted to humiliate them. They often use derogatory terms against the players telling them to "man up" or to stop "playing like pussies", or telling them that they throw/run/play like a girl. It is believed that the worst thing to be called or compared to in sports is a female. In addition, it is one of the easiest ways to curb someone down. Demeaning statements like this about women only reinforce that the sports world is no place for a woman.

Women's athletic abilities are considered far inferior and their competition less intense than any man's, apparent through the lack of media and commercialization efforts directed toward the benefit of the female gender. Therefore, the media coverage given to male athletes compared to females is a ratio heavily favouring men. In terms of coverage, $90.1 \%$ of editors and $87.4 \%$ of reporters working in sports journalism are male (Musto, et al., 2017). In visual media, approximately $95 \%$ of anchors and co-anchors are male (Cooky et al., 2015). Moreover, even in terms of payment male athletes get paid more than females which shows a bias based on gender within the sport.

Feminist scholarship has had a profound impact upon the study of sports, exposing the gendered nature of these activities and questioning the traditional exclusion and marginalization of most females from sports (Kidd, 2013). Cinema being an art and a media form has been faithfully reflecting as well as influencing social structures for more than 100 years. Movies cannot function in isolation. Either they are the reflection of society or they tend to change the accepted social order by displaying the truth. Sports is an area which has been effectively dealt by cinema. In the Indian context, particularly in this decade, there has been a huge rise in the number of movies depicting the life or activities of sportspersons. This research study explores the misogyny in two movies, reflecting how Indian sportswomen confront social as well as cultural stereotypes with reference to participation in sports.

\section{Methodology and Procedures}

This research paper presents a thematic study of the misogyny faced by Indian sportswomen at different levels. It analyses two selected movies; Chak de! India (2007) and Dil bole Hadippa! (2009). Only movies released during the period from 2005 to 2010 were selected for this study. The main reason for the selection of this time frame is that during this period the Indian cinema witnessed a recent surge in the production of sports movies with female lead. Both of the movies emphasize the problems faced by Indian sportswomen of those sports that are traditionally linked to men. The movies also show how women are discouraged from participating and competing in sports, delineating the masculine vision of women as fragile 
and less competent. The protagonists of the movies experience sexism at familial, social, and professional levels in sports because of their being born as female.

In order to obtain a comprehensive list of all the Indian sports films produced during the selected period, online databases have been explored. This includes National Film Archive of India (NFAI), imdb.in and Wikipedia .The method adopted in this study is a detailed thematic analysis of two sports movies. The feminist approach is also invoked in framing misogyny in sports. Secondary sources related to the field of film studies in the form of books and research articles also constitute the conceptual framework of this study.

\section{Results and Discussion}

Chak de India (2007) explores the misogyny prevailing in the society and the perception of sports as a masculine sphere where women cannot outshine. The movie is about a group of 16 women hockey players who struggle to prove their mettle in a male dominated society for themselves. Being rejected by the sports officials, Kabir Khan, an ostracized former hockey captain of the national team takes up the challenge of coaching them. Surpassing problems such as gender discrimination, lack of moral support, denial of opportunities, they ultimately become successful. The biggest obstacle before them was the stance of the patriarchal world towards women sportspersons. One of the players, Komal Chautala, has to quarrel with her parents to get consent to play hockey and to be a part of the national hockey team. The team captain Vidya Sharma too has to endure opposition at different levels. Another player, Preeti's fiancé the Vice Captain of national cricket team- feels insecure because of her involvement with the team.

Most of the officials believe that investing money or even hopes in women hockey team is futile and is of little worth. Nobody is devoted to coach women hockey team and it surprises people when Kabir Khan offers to train the women hockey team. Mr. Tripathi, the crucial authority in Indian Hockey Association, doesn't have any hope for the women team. He is a custodian of male chauvinism, believing that the role of women is to engage in household chores like cooking and cleaning. In the movie we see that the officials are not interested in sponsoring the women's team. The chief Mr. Tripathi does not believe in the talent of woman players and comments that "Team like this will never win even with a European school team". He also believes that there is no need of providing much support to women's team. He tells the coach that "You must know that country like ours keep women's hockey team for the name sake. Not for the job". He also makes comparison between the men's team and women's team and also calls the latter as team of misfits.

In order to obtain permission to participate in the World Cup, the women hockey team had to convince the authorities with their performance. They had to play a match against Men's hockey team and beat the latter so that only they could take part in the World Cup. The male team believed that they could beat them very easily. In the boys versus girls hockey match girls nearly beat the boys, and are able to convince the authorities to give them consent to take part in the World Cup tournament. 
In the movie, we could see that these women players have to encounter many difficult periods in their life. They had to fight against the opponent teams and also against their own people who disbelieve in their abilities, in addition to grappling with the factionalism within the team. Ultimately, they fight alone and eventually win. The movie is not just a cinematic account of events; rather, it is in fact a representation of reality. The movie with its feminist attitude stands for faith in abilities of women. In the movie, we see that one of the players, Preeti, shuns her fiancé and pursues her career in sports. She refuses to marry him due to his misogynistic attitude. Another sportswoman, Vidya, too prefers sports and does not return to her husband's family who had given her choices either to be a homemaker or just play hockey.

Pitched against the mass of anti-women sports authorities, biased male sportspersons and a disinterested public, we see a determined team supported by a dedicated coach. Despite all odds, the coach stands boldly with his team and proves their merit. The movie portrays women empowerment when we see self confidence increasing in women, so much so that they give a strong blow to the boys' team. In the movie, Kabir makes a statement: "Your match isn't against these 16 boys; it's against every idiot who has forgotten that if a woman can give birth to him, she can do anything." This statement is crucial in building self-confidence in them and they prove at different levels that they are not subordinate to men.

The movie debunks all the myths like "women cannot play properly", "women cannot win", etc. It also evidently explains how the people in power who are supposed to handle the sports association. It demonstrates how authorities do not take women's sports gravely and do not look after their requirements. The movie was a big hit at the Box Office and became a great inspiration for all the girls who wanted to pursue sports as a career. It was also a wake-up call for the society which thinks that sports are just masculine.

Dil Bole Hadippa! (2009) is a movie that destabilizes the patriarchal viewpoints about sportswomen. Thus it provides a new room for movies that challenges the basic assumptions of mainstream sports movies. Dil bole Hadippa! delineates the life of a Punjabi girl, Veera, (Rani Mukherjee) who dreams of becoming a cricket player. The protagonist of the movie Rohan is the captain of a provincial cricket team in England. Rohan's Father Vicky (Anupam Kher) fakes a heart attack to call him back from England and persuades him to become the captain and coach the Indian Team for an upcoming match against Pakistan. Veera is the best cricket player of her state, but since she is a woman, no one takes her seriously, and she is not allowed to join the new cricket team of India. Later, Veera disguises herself as a man and goes for the audition as Veer and gets selected as an opening batsman. In the end, when it is revealed to Rohan, he refuses to let her play because she deceived him and a woman is not supposed to be on the team. Whereas, when he realizes how important it is for his father that India wins the match, he allows Veera to play. In the final, Veera shows her talent and leads the team to victory. In the climax of the movie, it is publicized by Rohan that Veer is actually a girl and Veera gives an empowering speech.

Anurag Singh in Dil Bole Hadippa employs the method of masquerade which helps him to challenge the prevailing male gaze. He makes the female character wear a mask to create a 
detachment between the two versions of the woman character on screen, the feminine and the disguised, and between the spectators and disguised image. Audience sees Veera, both as a girl as well as Veer, disguised as a cricket player. This Veera is a possible alternative to the represented femininity in Bollywood sports movies. The distance created helps the spectator to figure out the difficulty of being a woman in a patriarchal world. This can be observed when Veera is not allowed to enter the audition because players have to be male. It is this disguise that also helps Veera to protect herself from adverse situations. For example, when Rohan, the coach, accidentally finds Veera in the dressing room, Veera makes up the story of being the sister of Veer. As Rohan falls in love with Veera, Veera shuffles between the roles of Veer and Veera. Veera's mask fells off only after cementing her position in the team and so even after the exposure of her identity she becomes an irreplaceable member of the team for the coach. Not only her talent is recognised in this big male world of cricket but at the same time the mask helped her to enjoy the alternative masculine position. Thus when she reveals her identity she can demand for the recognition of talent in spite of male female divide. Though the plea, talented woman must be allowed to play in the men's team, is utopian what probably the director and his team wanted to establish is that women athletes require considerate support from their partners and not patriarchal control and regimentation to achieve their desired goals.

In the movie, it's mentioned a number of times that Veera should play with women alone and not with men. There is casual prejudice to many of the male parts as they cannot understand or accept being beaten by a woman. This aspect reaches its absurd peak when Veer is revealed as Veera and there is an allegation of deception. While the character of Veera is an incarnation of equality and ultimately triumphant, it's something that could have possibly been explored further.

The movie does not revolve exclusively around the women's sports as the other movies but it raises a significant question about why a woman who has the same ability as that of a man cannot play in a men's team. Though the film was unsuccessful at the Box Office, it left the sports enthusiasts with a question about why there are mixed teams in games like Badminton which are considered "suitable" for women but the category of mixed teams does not exist in the games like Cricket, Hockey, Football etc which are considered to be masculine in nature.

\section{Conclusion and Suggestion}

The thematic analysis of the selected two movies reveals that there are attempts to expose misogyny in sports. Chak De! India is a 2007 sports movie which explores the sexism ubiquitous in the domain of sports. Dil Bole Hadippa! is a 2009 movie that raises an important question about why a woman who has the same talent as a man cannot play in a men's team. Both of these movies project their protagonists struggling to achieve success in sports. In the two movies, the protagonists become eventually successful, and this is just done so that the movie would be well-received by audience. Unfortunately, real life stories are different. Misogyny is deep-rooted in sport institutions though there have been many efforts to pact with the crisis. With social media's increasing popularity, women sports are coming to sphere rapidly. Although these movies have their own drawbacks, they have been able to give a 
message that men cannot assert sports as their private sphere and the society cannot deny women equal rights of participation and opportunity in sports.

In this research paper, the attempt is to subvert the notion that sports are the exclusive domain of men alone. From a feminist perspective, sports are an activity and career that women have to enter. Indeed, there is a growing concern about women wider inclusion in sports, but the feminist inquiry has to keep investigating discrimination and objectification of the female body. Since this study is limited to the analysis of two movies, it is recommended that further research studies be conducted with a wider sample and more recent movies.

\section{Conflict of Interest}

The author of the article declares no conflict of interest.

\section{Funding}

This research study was not funded by any institution. The author conducted the study on his own expenses.

\section{References}

Burton, L. J. (2015). Underrepresentation of women in sport leadership: A review of research. Sport management review, 18(2), 155-165.

Costa, D. M., Costa, D. M., \& Guthrie, S. R. (1994). Women and sport: Interdisciplinary perspectives. Human Kinetics. netics.

Creedon, P. J. (2000). Women, media, and sport: Challenging gender values. Thousand Oaks, CA: Sage Publ.

Dolance, S., \& Messner, M. A. (2003). Taking the Field: Women, Men, and Sports. Contemporary Sociology, 32(5), 560. doi:10.2307/1556461

Cooky, C., Messner, M. A., \& Musto, M. (2015). “It's dude time!” A quarter century of excluding women's sports in televised news and highlight shows. Communication \& Sport, 3(3), 261-287.

Hanson, V. (2012). The inequality of sport: Women< men. The Review: A journal of undergraduate student research, 13(1), 15-22.

Kidd, B. (2013). Sports and masculinity. Sport in society, 16(4), 553-564.

Mukherjee, A. (2018). Representational Politics in Bollywood Sports Movies of the 21st Century: Empowering Women through Counter Cinema. postscriptum, 3(2), 65-80. doi:10.5281/zenodo.1318946

Musto, M., Cooky, C., \& Messner, M. A. (2017). “From Fizzle to Sizzle!” Televised sports news and the production of gender-bland sexism. Gender \& Society, 31(5), 573-596. doi:10.1177/0891243217726056.

Senne, J. A. (2016). Examination of gender equity and female participation in sport. The Sport Journal, 19, 1-9. 


\section{Filmography}

Chak De! India. Dir. Shimit Amin. Prod: Yashraj Films. 2007.

Dil Bole Hadippa!. Dir. Anurag Singh. Prod: Aditya Chopra. Yash Raj Films. 2009. DVD. 